Bibliotech : Jurnal Ilmu Perpustakaan dan Informasi, 3 (1) 2018

\title{
BIBLIOTERAPI DALAM PERAWATAN PASIEN ANAK DI RSI BANYUBENING SERTA TINJAUANNYA MENURUT ISLAM
}

\author{
Erviana Dwinugrahaningtyas ${ }^{*}$; Nita Ismayati ${ }^{*}$ \\ ${ }^{1}$ Perpustakaan Nasional RI \\ ${ }^{2}$ Universitas YARSI \\ *Korespondensi: erviana.dwi@perpusnas.go.id; n.ismayati@yarsi.ac.id
}

\begin{abstract}
ABSTRAK
Biblioterapi sudah lama digunakan sebagai terapi tambahan dalam kedokteran dan psikiatri untuk membantu penyembuhan pasien melalui bahan bacaan terpilih. Rumah Sakit Islam Banyubening, Boyolali, telah melakukan kegiatan biblioterapi sederhana untuk pasien anak-anak namun belum diketahui bagaimana peran biblioterapi yang telah dilakukan terhadap perawatan pasien anak-anak tersebut. Penelitian ini bertujuan untuk mengetahui bagaimana peran biblioterapi dalam perawatan pasien anak di RSI Banyubening dan bagaimana tinjauan Islam terhadap bacaan bagi orang sakit. Jenis penelitian kuantitatif. Teknik pengambilan sampel menggunakan sampel jenuh. Jumlah sampel 7 orang. Pengambilan data melalui observasi dan kuesioner. Hasil penelitian diketahui bahwa layanan biblioterapi berperan positif dalam perawatan pasien anak di RSI Banyubening. Responden selain mendapatkan pengetahuan dan menurunkan stress di rumah sakit, juga merasa senang dan nyaman, yang dapat membantu proses penyembuhan penyakit. Tinjauan Islam terhadap bacaan bagi orang sakit yaitu Al-Qur'an merupakan sebaik-baik bacaan yang bagi orang sakit yang dapat memberikan kedamaian hati dan ketenangan jiwa sehingga memperoleh kesembuhan yang lebih cepat. Rekomendasi penelitian agar pihak RSI Banyubening meningkatkan layanan biblioterapi melalui peningkatan kemampuan SDM dan pemberian bacaan Al Qur'an secara berkala terhadap pasien beragama Islam.
\end{abstract}

Kata kunci: Biblioterapi, perawatan pasien anak, perpustakaan rumah sakit, RSI Banyubening

\section{PENDAHULUAN}

Undang-Undang No 44 tahun 2009 tentang Rumah Sakit menyebutkan bahwa rumah sakit merupakan institusi pelayanan kesehatan yang menyelenggarakan pelayanan kesehatan perorangan secara paripurna yang menyediakan pelayanan rawat inap, rawat jalan, dan gawat darurat. Pelayanan secara paripurna ini ditujukan kepada pasien agar mendapatkan pemulihan kesehatan baik secara fisik maupun psikis (Indonesia, 2010). Dari definisi ini jelas disebutkan bahwa rumah sakit tidak hanya bertujuan untuk memulihkan pasien secara fisik namun juga secara psikis. Salah satu upaya yang dilakukan untuk pemulihan pasien secara psikis yaitu dengan menyediakan sarana untuk mendorong penyembuhan pasien secara psikis salah satunya adalah dengan mendirikan perpustakaan rumah sakit.

Perpustakaan rumah sakit merupakan salah satu unit yang berperan serta membantu 
rumah sakit dalam mewujudkan visi dan misinya, yaitu memberikan layanan kesehatan fisik dan mental kepada pasien yang berobat (Yolanda \& Ismayati, 2015). Berdasarkan Standars for Hospital Libraries tahun 2007 peran perpustakaan rumah sakit yaitu memberikan layanan informasi dan pendidikan kepada masyarakat di lingkungannya, termasuk juga pasien. Pemerintah juga mendorong berdirinya perpustakaan rumah sakit dengan mengeluarkan SK MENKES NO. 436/MENKES/SK/VI/1993 yang telah menetapkan 20 Standar Pelayanan Rumah Sakit, yang salah satu diantaranya adalah perpustakaan (Indonesia, 1994).

Di negara-negara maju, perpustakaan rumah sakit tidak hanya berperan dalam meningkatkan pengetahuan para dokter dan tenaga medis lainnya, namun juga berperan aktif dalam upaya penyembuhan pasien. Sedangkan di Indonesia perpustakaan rumah sakit belum banyak berperan aktif dalam upaya penyembuhan pasien, kebanyakan perpustakaan rumah sakit di Indonesia masih menitikberatkan perannya hanya pada penyediaan informasi bagi para dokter ataupun tenaga medis lainnya. Dari hasil wawancara yang dilakukan peneliti dengan pustakawan madya di perpustakaan kementerian kesehatan diketahui bahwa dari 32 rumah sakit vertikal kementerian kesehatan yang ada di seluruh Indonesia, belum semuanya memiliki perpustakaan, yang sudah memiliki perpustakaan sementara ini hanya berkewajiban untuk menyediakan informasi bagi dokter dan tenaga medis saja, belum merambah kepada penyediaan buku untuk pasien.

Seperti diketahui, menjalani perawatan membuat pasien jenuh dan tertekan secara mental, apalagi bila kondisi ini terjadi pada pasien anak-anak. Berdasarkan penelitian yang dilakukan oleh I. Coyne, disebutkan bahwa anak yang menjalani perawatan inap mengalami kecemasan dan kegelisahan karena perpisahan dengan orang tua dan keluarga, prosedur pemeriksaaan dan pengobatan, dan akibat berada di lingkungan asing (Coyne, 2006). Anak yang menjalani perawatan di rumah sakit terpaksa harus berpisah dengan orang orang dan lingkungan yang dikenalnya, setiap hari dikelilingi wajah asing dan menjalani perawatan secara berulang-ulang, sehingga sering dijumpai anak-anak yang menjalani perawatan terlihat lesu dan kurang bersemangat. Salah satu hiburan adalah menunggu kunjungan dari keluarga dan kerabat namun ini juga dibatasi oleh jam berkunjung.

Keadaan ini diperburuk bila komunikasi antara tenaga medis dan pasien tidak berjalan dengan lancar, bila komunikasi antara tenaga medis dengan pasien berjalan dengan baik, maka dapat menghilangkan ketakutan dan meningkatkan kesehatan secara mental, sebaliknya 
Bibliotech : Jurnal Ilmu Perpustakaan dan Informasi, 3 (1) 2018

kurangnya komunikasi yang baik dalam perawatan kesehatan mengakibatkan hasil kesehatan yang buruk. Salah satu cara untuk menjembatani hal ini adalah melalui biblioterapi (Sherrill \& Harris, 2014).

Biblioterapi berasal dari kata biblion dan therapeia. Biblion berarti buku atau bahan bacaan, sementara therapeia artinya penyembuhaan, jadi biblioterapi dapat diartikan sebagai memanfaatkan buku sebagai sarana terapi untuk mencapai kesembuhan. Dengan membaca kita dapat memperoleh ilmu pengetahuan, informasi, hiburan dan hal lain yang bermanfaat, membaca juga dapat memberikan pandangan yang positif sehingga menggugah pasien untuk berjuang melawan penyakitnya. Dengan bacaan yang menginspirasi diharapkan pasien anak menjadi lebih bersemangat, dan terhindar dari stress. Dengan menggunakan buku, dimungkinkan untuk membahas dan menganalisis situasi dengan cara yang tidak menakutkan, memfasilitasi penangkapan/pemahaman makna, dan meningkatkan pengetahuan (Lucas \& Soares, 2013).

Rumah Sakit Islam Banyubening merupakan rumah sakit swasta yang terletak di kabupaten Boyolali, Jawa Tengah. Rumah Sakit ini mempunyai misi untuk memberikan edukasi kesehatan kepada masyarakat di sekitarnya. Rumah Sakit Islam (selanjutnya RSI) Banyubening juga berkeinginan untuk menyediakan sarana pemulihan kesehatan terbaik kepada pasien, baik secara fisik maupun psikis. Salah satu bentuk sarana pemulihan kesehatan secara psikis yang dilakukan yaitu dengan memberikan layanan biblioterapi. Layanan biblioterapi yang diberikan, tidak hanya dengan membuat pojok baca yang terbuka bagi masyarakat umum, namun juga dengan cara menempatkan koleksi buku di dalam kamar perawatan pasien. Hal ini dilakukan sebagai upaya untuk mendekatkan buku kepada pasien, dengan harapan dapat berperan untuk membantu perawatan pasien, yang menjadi pertanyaan sekarang adalah apakah layanan biblioterapi yang telah dilakukan memiliki peran terhadap perawatan pasien, dalam hal ini khususnya pasien anak.

\section{METODE}

Jenis penelitian dalam penelitian ini adalah kuantitatif dengan metode deskriptif. Populasi yaitu pasien anak yang dirawat inap di RSI Banyubening, sedangkan teknik pengambilan sampel menggunakan non probability sampling dengan jenis sampling jenuh, yaitu mengambil semua anggota populasi sebagai sampel. Pengambilan sampel jenuh juga dimaksudkan untuk 
mendapatkan gambaran yang menyeluruh mengenai peran biblioterapi di RSI Banyubening terhadap pasien rawat anak. Jumlah sampel dalam penelitian ini berjumlah 14 orang, terdiri dari pasien anak 7 orang dan orang tua pasien 7 orang. Dua orang pasien tidak disetujui oleh orang tuanya untuk dijadikan responden.

Instrumen yang digunakan untuk pengumpulan data meliputi observasi dan kuesioner. Observasi dilakukan di perpustakaan RSI Banyubening, untuk mengamati layanan biblioterapi yang diberikan oleh perpustakaan RSI Banyubening dan perannya terhadap perawatan pasien anak. Setelah melakukan observasi, peneliti memberikan kuesioner kepada pasien rawat inap dan orang tua pasien untuk mengisi data data yang dibutuhkan. Kuesioner untuk pasien anak dibedakan menurut usia yaitu pasien anak dibawah usia 10 tahun dan di atas usia 10 tahun. Kuesioner dibedakan menjadi 2 kelompok usia berdasarkan kemampuan berpikir seorang anak, yaitu pada usia diatas 10 tahun seorang anak memasuki tahap masa remaja (adolesent), anak sudah mampu berpikir abstrak, mampu berpikir secara "ilmiah", dan mampu memecahkan masalah secara logis, sehingga dapat memahami isi cerita dengan baik. Sedangkan anak dibawah usia 10 tahun masih memerlukan bimbingan untuk dapat memahami isi dari cerita (Nurgiyantoro, 2005). Pengisian kuesioner pada pasien anak dilakukan dengan cara dibacakan, yaitu peneliti membacakan pertanyaan dan pasien anak menjawabnya. Data yang telah diperoleh kemudian diolah dan dianalisis dengan teknik analisis deskriptif kuantitatif, yaitu dengan cara mendeskripsikan data yang telah terkumpul apa adanya tanpa bermaksud membuat kesimpulan yang berlaku umum.

\section{HASIL DAN PEMBAHASAN}

\subsection{Hasil}

Dari hasil observasi diketahui bahwa perpustakaan RSI Banyubening telah memberikan layanan biblioterapi, tidak saja kepada pasien anak tetapi juga kepada pasien dewasa, baik yang dirawat inap maupun yang berobat jalan. Layanan biblioterapi yang diberikan selain layanan di pojok baca perpustakaan yang terletak di bagian poliklinik RSI banyubening, juga berupa layanan aktif berupa penyediaan koleksi buku di dalam ruang rawat pasien. Layanan pojok baca dimanfaatkan oleh pasien yang melakukan pemeriksaan kesehatan, tenaga medis, dan masyarakat. Selain buku, di pojok baca ini juga disimpan berbagai macam brosur mengenai informasi kesehatan yang dapat diambil secara gratis. 
Dalam penelitian ini, peneliti mendapat kesempatan untuk melakukan kegiatan pembacaan buku (story telling) dan diskusi setiap hari pada pukul 8-10 pagi dan pukul 4-6 sore hari, berdasarkan pengamatan didapatkan hasil bahwa pasien anak lebih menyukai kegiatan biblioterapi di pagi hari dan kurang merespon bila dilakukan biblioterapi di sore hari. Hal ini disebabkan karena pada sore hari biasanya anak-anak suka menonton televisi, main game, dan banyak teman atau kerabat yang menjenguk.

Dari hasil observasi terlihat bahwa biblioterapi memiliki peran dalam perawatan pasien anak. Hal ini dibuktikan ketika ada seorang pasien anak berusia dibawah 10 tahun yang beberapa hari rewel, dan ketika dibacakan cerita dengan buku yang sesuai dengan usianya, pasien tersebut tampak antusias mendengarkan, kemudian tertarik untuk memegang buku sendiri, bahkan berkeinginan memiliki buku tersebut. Pada saat yang lain, ketika peneliti melakukan layanan biblioterapi yang berselang satu hari, ada pasien yang menanyakan kepada perawat mengapa hari itu dia tidak mendapatkan layanan biblioterapi. Dari hasil observasi diketahui bahwa pasien anak usia dibawah 10 tahun lebih menyukai dibacakan cerita mengenai kisah-kisah pendek dari Al Qur'an dan cerita binatang. Setiap selesai membacakan cerita, peneliti mengadakan diskusi singkat mengenai isi buku, dan respon yang diberikan oleh pasien cukup baik. Hal ini sesuai dengan harapan karena pada anak-anak biblioterapi digunakan sebagai sarana untuk pengalihan perhatian, memberi hiburan, untuk mengurangi stres, dan menimbulkan kenyamanan (McMillen dan Pehrsson, 2008).

Peran dari biblioterapi juga terlihat pada pasien anak yang berusia diatas 10 tahun dengan penyediaan buku-buku yang menarik, dan mereka tampak menikmati proses membaca, peneliti membawa beberapa subjek buku, dan terlihat bahwa anak-anak di atas usia 10 tahun lebih memilih untuk membaca buku buku tentang tokoh-tokoh yang menginspirasi, dan buku pengetahuan. Selesai mereka membaca buku, peneliti mengadakan diskusi singkat mengenai buku yang mereka baca, dan pasien memberi respon yang baik. Diskusi dilakukan untuk mengetahui sejauh mana mereka memahami dan dapat mengambil manfaat dari buku yang mereka baca. Hasil lain dari kegiatan ini adalah meningkatnya minat baca dari pasien anak, hal ini dapat dilihat dari atusiasme mereka yang meminta peneliti untuk meminjamkan buku buku lain, selain yang tersedia di kamar perawatan.

Terdapat dua jenis kuesioner yang diberikan kepada responden, yaitu kuesioner untuk pasien, dan kuesioner untuk orang tua pasien. Kuesioner untuk pasien dibedakan lagi 
Bibliotech : Jurnal Ilmu Perpustakaan dan Informasi, 3 (1) 2018

menjadi dua, yaitu kuesioner untuk pasien yang berusia berusia 10 tahun ke bawah dan pasien berusia 10 tahun ke atas. Jumlah responden dapat dilihat dalam tabel 1 berikut:

Tabel 1. Jumlah Responden

\begin{tabular}{|l|l|l|}
\hline No & \multicolumn{1}{|c|}{ Responden } & Jumlah \\
\hline 1. & Pasien Anak Usia Dibawah 10 Tahun & 3 orang \\
\hline 2. & Pasien Anak Usia Diatas 10 Tahun & 4 orang \\
\hline 3. & Orang Tua Pasien & 7 orang \\
\hline
\end{tabular}

Berdasarkan hasil kuesioner didapatkan hasil bahwa seratus persen responden menyatakan senang dibacakan cerita. Responden juga menyatakan mau mendengarkan cerita dan ingin dibacakan cerita setiap harinya sebagaimana dapat dilihat pada tabel 2.

.Tabel 2. Isian Kuesioner Isian Kuesioner Responden Usia di Bawah 10 Tahun

\begin{tabular}{|c|c|c|c|c|c|}
\hline \multirow[t]{2}{*}{ No } & \multirow[t]{2}{*}{ Pertanyaan } & \multicolumn{3}{|c|}{ Responden } & \multirow[t]{2}{*}{ Alternatif Jawaban } \\
\hline & & I & II & III & \\
\hline 1. & $\begin{array}{l}\text { Apakah adik senang } \\
\text { dibacakan cerita? }\end{array}$ & $\sqrt{ }$ & $\sqrt{ }$ & $\sqrt{ }$ & $\begin{array}{l}\text { Ya, Suka } \\
\text { Tidak suka, jika tidak mengapa ? } \\
\text { (Jawaban bisa lebih dari 1) } \\
\text { a. Cerita membosankan } \\
\text { b. Gaya bercerita tidak menarik c. } \\
\text { Sedang sakit } \\
\text { d. Sedang sedih } \\
\text { e. sebab lainnya.................. }\end{array}$ \\
\hline 2. & $\begin{array}{l}\text { Apakah adik mau } \\
\text { mendengarkan cerita } \\
\text { lagi? }\end{array}$ & $\sqrt{ }$ & $\sqrt{ }$ & $\sqrt{ }$ & $\begin{array}{l}\text { Ya, mau } \\
\text { Tidak mau, jika tidak mengapa ? } \\
\text { (Jawaban bisa lebih dari 1) } \\
\text { a. Cerita membosankan } \\
\text { b. Gaya bercerita tidak menarik c. } \\
\text { Sedang sakit } \\
\text { d. Sedang sedih } \\
\text { e. sebab lainnya.................... }\end{array}$ \\
\hline 3. & $\begin{array}{l}\text { Apakah adik ingin } \\
\text { dibacakan cerita setiap } \\
\text { hari? }\end{array}$ & $\sqrt{ }$ & $\sqrt{ }$ & $\sqrt{ }$ & $\begin{array}{l}\text { Ya, ingin } \\
\text { Tidak ingin }\end{array}$ \\
\hline
\end{tabular}

Hal ini menunjukkan bahwa responden menyukai dibacakan cerita dan berkeinginan untuk dibacakan cerita setiap harinya. Anak-anak di bawah usia 10 tahun memerlukan bimbingan untuk mengerti isi dari sebuah cerita, sesuai dengan pendapat dari McMillen dan Pehrsson yang menyatakan bahwa untuk anak-anak kecil diperlukan fasilitator dalam kegiatan biblioterapi untuk membantu mereka mengenali kesamaan antara keadaan mereka dengan karakter dalam 
cerita.

Berdasarkan hasil dari kuesioner didapatkan hasil bahwa seratus persen responden menyukai dan merasa terhibur dengan kegiatan bercerita dan diskusi setelah kegiatan bercerita sebagaimana terlihat di Tabel 3.

Tabel 3. Isian Kuesioner Responden Usia di Atas 10 Tahun

\begin{tabular}{|c|c|c|c|c|c|c|}
\hline \multirow[t]{2}{*}{ No } & \multirow[t]{2}{*}{ Pertanyaan } & \multicolumn{4}{|c|}{ Responden } & \multirow[t]{2}{*}{ Alternatif Jawaban } \\
\hline & & I & II & III & IV & \\
\hline 1. & $\begin{array}{l}\text { Apakah adik } \\
\text { menyukai } \\
\text { kegiatan } \\
\text { bercerita dan } \\
\text { tanya jawab } \\
\text { yang dilakukan? }\end{array}$ & & & & & $\begin{array}{l}\text { Ya, suka } \\
\text { Tidak suka, jika tidak } \\
\text { mengapa ? (Jawaban bisa } \\
\text { lebih dari 1) } \\
\text { a. Cerita membosankan } \\
\text { b. Gaya bercerita } \\
\text { tidak menarik } \\
\text { c. Sedang sakit d. Sedang } \\
\text { sedih } \\
\text { e. sebab lainnya..... }\end{array}$ \\
\hline 2. & $\begin{array}{l}\text { Apakah adik } \\
\text { Merasa terhibur } \\
\text { dengan adanya } \\
\text { kegiatan } \\
\text { bercerita dan } \\
\text { tanya jawab ini? }\end{array}$ & & & & & $\begin{array}{l}\text { Ya } \\
\text { Tidak, jika tidak } \\
\text { mengapa ? (Jawaban bisa } \\
\text { lebih dari 1) } \\
\text { a. Cerita membosankan } \\
\text { b. Gaya bercerita tidak } \\
\text { menarik } \\
\text { c. Sedang sakit d. Sedang } \\
\text { sedih e.sebab lainnya.......... }\end{array}$ \\
\hline 3 & $\begin{array}{l}\text { Menurut adik, } \\
\text { apakah ada } \\
\text { manfaat yang } \\
\text { diperoleh dari } \\
\text { membaca buku } \\
\text { bacaan tersebut? }\end{array}$ & $\begin{array}{l}\text { Tidak } \\
\text { memikir } \\
\text { kan sakit } \\
\text { lagi }\end{array}$ & $\begin{array}{l}\text { Bisa } \\
\text { mengetah } \\
\text { ui } \\
\text { salahsatu } \\
\text { sifat } \\
\text { Rasululla } \\
\text { h }\end{array}$ & $\begin{array}{l}\text { Menghila } \\
\text { ngkan } \\
\text { kebosa- } \\
\text { nan }\end{array}$ & $\begin{array}{l}\text { Mengenal } \\
\text { ilmuwan } \\
\text { muslim }\end{array}$ & $\begin{array}{l}\text { Ada, } \\
\text { sebutkan.................... } \\
. \\
\text { Tidak ada }\end{array}$ \\
\hline 4 & $\begin{array}{l}\text { Menurut adik, } \\
\text { Apakah buku yang } \\
\text { ada cukup } \\
\text { menarikuntuk } \\
\text { dibaca? }\end{array}$ & $\sqrt{ }$ & $\sqrt{ }$ & $\sqrt{ }$ & $\sqrt{ }$ & $\begin{array}{l}\text { Ya, menarik } \\
\text { Tidak menarik }\end{array}$ \\
\hline
\end{tabular}


Bibliotech : Jurnal Ilmu Perpustakaan dan Informasi, 3 (1) 2018

\begin{tabular}{|c|c|c|c|c|c|c|}
\hline \multirow[t]{2}{*}{ No } & \multirow[t]{2}{*}{ Pertanyaan } & \multicolumn{4}{|c|}{ Responden } & Alternatif Jawaban \\
\hline & & $\mathbf{I}$ & II & III & IV & \\
\hline 5 & $\begin{array}{l}\text { Adik lebih } \\
\text { menyukai } \\
\text { membaca sendir } \\
\text { Atau dibacakan } \\
\text { cerita? }\end{array}$ & $\sqrt{ }$ & $\sqrt{ }$ & $\sqrt{ }$ & $\sqrt{ }$ & $\begin{array}{l}\text { Membaca sendiri } \\
\text { Dibacakan }\end{array}$ \\
\hline
\end{tabular}

Mereka juga dapat merasakan manfaat dari kegiatan ini. Hal tersebut membuktikan bahwa responden menyukai dan merasa terhibur dengan kegiatan ini, bahkan dapat merasakan manfaat dari buku bacaan yang dibaca. Sesuai dengan pendapat para ahli bahwa biblioterapi mempunyai manfaat sebagai nurturent effect yakni diperolehnya pengetahuan tentang materi bacaan, timbul sikap kritis, dan menambah wawasan pembaca melalui penumbuhan kesadaran khususnya moral (Dewi \& Prihartanti, 2014). Dari hasil kuesioner diketahui bahwa responden dengan usia di atas 10 tahun merasakan beberapa manfaat dari membaca buku sebagaimana terlihat pada gambar 1 berikut :

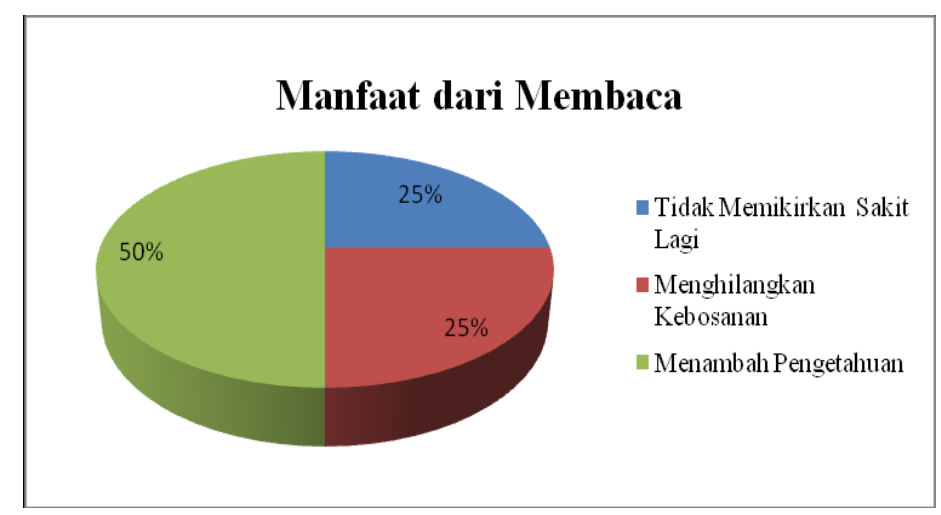

Gambar 1. Manfaat yang dirasakan responden usia di atas 10 tahun

Seluruh responden juga lebih menyukai membaca cerita sendiri. Hal ini sesuai dengan pendapat McMillen dan Pehrsson, yang menyatakan bahwa pada anak-anak yang dengan kategori remaja, bantuan untuk membaca kurang dibutuhkan (McMillen \& Pehrsson, 2008).

Berdasarkan hasil kuesioner yang diisi oleh orang tua responden, diperoleh gambaran bahwa bahwa $96 \%$ orang tua pasien berpendapat kegiatan bercerita ini bagus untuk anak anak, diantaranya adalah untuk menghibur dan menambah wawasan anak-anak. 
Tabel 4. Isian Kuesioner Orang Tua Responden

\begin{tabular}{|c|c|c|c|c|c|c|c|c|}
\hline \multirow[t]{2}{*}{ No } & \multirow[t]{2}{*}{ Pertanyan } & & & \multicolumn{5}{|c|}{ Responden } \\
\hline & & I & II & III & IV & $\mathbf{V}$ & VI & VII \\
\hline 1. & $\begin{array}{l}\text { Bagaimana } \\
\text { pendapat } \\
\text { Bapak/Ibu } \\
\text { mengenai } \\
\text { kegiatan } \\
\text { bercerita ini } \\
?\end{array}$ & $\begin{array}{l}\text { Tergantung } \\
\text { Pada anak, } \\
\text { jika anak } \\
\text { ingin } \\
\text { bermain } \\
\text { tidak } \\
\text { mungkin } \\
\text { mendengark } \\
\text { an cerita }\end{array}$ & $\begin{array}{l}\text { Bagus } \\
\text { Untuk } \\
\text { hiburan } \\
\text { anak }\end{array}$ & $\begin{array}{l}\text { Sangat } \\
\text { bagus }\end{array}$ & $\begin{array}{l}\text { Bagus, } \\
\text { karena } \\
\text { mengem- } \\
\text { bangkan } \\
\text { minat baca } \\
\text { anak }\end{array}$ & Bagus & $\begin{array}{l}\text { Bagus } \\
\text { untuk } \\
\text { menamba } \\
\text { h } \\
\text { wawasan } \\
\text { anak }\end{array}$ & $\begin{array}{l}\text { Bagus, bisa } \\
\text { menghibur } \\
\text { anak-anak } \\
\text { dan mening- } \\
\text { katkan minat } \\
\text { baca dan } \\
\text { dapat } \\
\text { pengalaman } \\
\text { dari kisah2 } \\
\text { tersebut }\end{array}$ \\
\hline 2. & $\begin{array}{l}\text { Apakah } \\
\text { menurut } \\
\text { Bapak/Ibu } \\
\text { buku bacaan } \\
\text { yang } \\
\text { disediakan } \\
\text { sudah } \\
\text { memenuhi } \\
\text { kebutuhan? }\end{array}$ & $\mathrm{Ya}$ & Belum & Sudah & Belum & Sudah & $\begin{array}{l}\text { lebih } \\
\text { diper- } \\
\text { banyak } \\
\text { lagi } \\
\text { koleksi } \\
\text { bacaan- } \\
\text { nya }\end{array}$ & $\begin{array}{l}\text { Kalo bisa } \\
\text { ditambah } \\
\text { koleksi buku } \\
\text { tentang } \\
\text { kisah tokoh2 } \\
\text { Islam yang } \\
\text { bisa } \\
\text { diteladani }\end{array}$ \\
\hline 3. & $\begin{array}{l}\text { Apa yang } \\
\text { Dirasakan } \\
\text { oleh } \\
\text { putra/putri } \\
\text { dari Bapak } \\
\text { /Ibu dengan } \\
\text { adanya } \\
\text { kegiatan } \\
\text { bercerita ini } \\
\text { ? }\end{array}$ & Senang & Senang & $\begin{array}{l}\text { Mengu } \\
\text { rangi rasa } \\
\text { takut di } \\
\text { rumah } \\
\text { sakit }\end{array}$ & $\begin{array}{l}\text { Mengu- } \\
\text { rangi } \\
\text { kejenuhan } \\
\text { anak }\end{array}$ & $\begin{array}{l}\text { Nyama } \\
\mathrm{n}\end{array}$ & Senang & $\begin{array}{l}\text { Senang, } \\
\text { terhibur }\end{array}$ \\
\hline
\end{tabular}

Hal ini membuktikan bahwa orang tua responden mengakui bahwa kegiatan biblioterapi ini bagus untuk anak mereka yang sedang dirawat, namun ada juga yang beranggapan bahwa efektifitas dari kegiatan ini tergantung pada keinginan pasien anak itu sendiri, seperti bila pasien anak sedang ingin bermain, tidak mungkin dipaksa untuk mendengarkan cerita, bermain yang dimaksudkan di sini adalah bermain game dengan permainan elektronik (hp, tab, dan lain sebagainya). Hasil kuesioner juga menunjukkan bahwa seratus persen responden menyatakan bahwa anak anak mereka senang dengan kegiatan biblioterapi sebagaimana yang terlihat pada Gambar 2. 


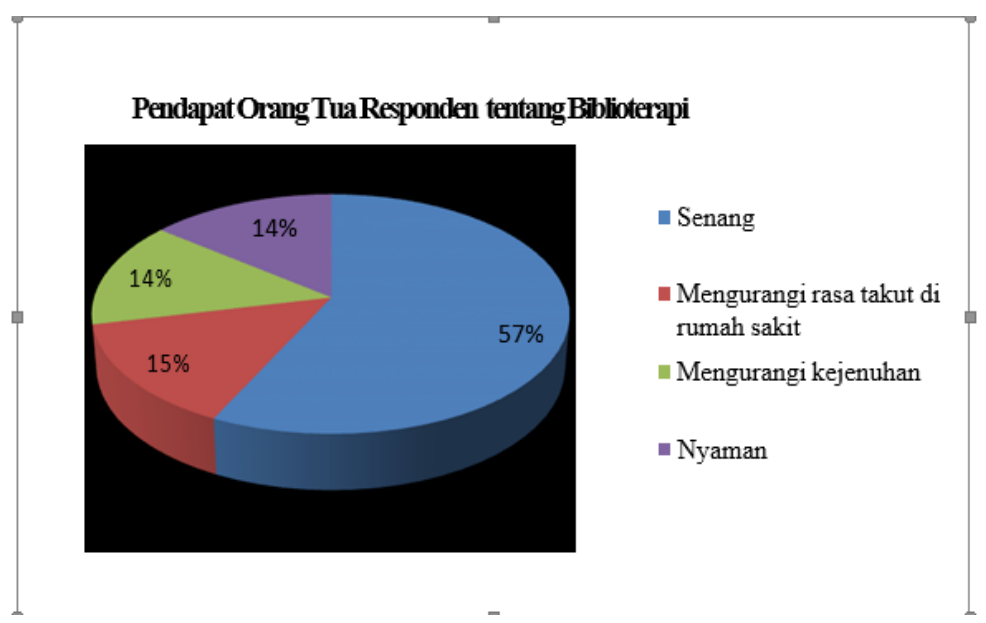

Gambar 2. Pendapat Orang Tua Responden tentang Manfaat Biblioterapi

Orang tua pasien juga menyatakan merasakan manfaat dari kegiatan ini, di antaranya adalah menambah pengetahuan dan membuat anak anak merasa seakan-akan tidak berada di rumah sakit. Hal ini membuktikan bahwa menurut orang tua pasien layanan biblioterapi mempunyai peran untuk memberikan pengaruh yang positif bagi perawatan pasien anak, diantaranyanya adalah anak merasa senang, terhibur, dan mengurangi kejenuhan. Sesuai dengan pendapat yang meyatakan bahwa buku sangat penting untung meningkatkan perkembangan emosi, sosial dan kognitif. Buku menuntun anak anak untuk berfikir, memperbaiki tingkah laku, bahkan membantu memecahkan masalah (Lucas, 2013).

Hal ini sejalan dengan penelitian sebelumnya tentang Layanan Biblioterapi untuk Pasien Kanker Anak di RSUP Fatmawati Yoanda (2015) bahwa biblioterapi dapat memberikan semangat dan motivasi hidup anak-anak penderita kanker. Juga penelitian yang dilakukan oleh Apriliawati (2011) yang menyatakan bahwa biblioterapi terbukti memberikan pengaruh terhadap penurunan tingkat kecemasan anak yang menjalani perawatan inap, sehingga anak akan lebih kooperatif dalam menjalankan perawatan, dan merasa lebih nyaman sehingga diharapkan dapat mempercepat proses penyembuhan pasien. Selain itu, Sherill dan Haris (2014) menyatakan bahwa kemampuan biblioterapi untuk membuat pasien merasa nyaman dan mengurangi stress sangat menguntungkan. Selain itu terapi membaca juga berkontribusi dalam peningkatan kemampuan pasien untuk berkomunikasi secara positif yang terbukti meningkatkan kepatuhan, sehingga memberikan hasil kesehatan yang lebih baik.

Biblioterapi harus dilaksanakan secara berkesinambungan (McMillen dan Pehrsson, 
Bibliotech : Jurnal Ilmu Perpustakaan dan Informasi, 3 (1) 2018

2008). Kegiatan biblioterapi pada pasien yang berkesinambungan tersebut meliputi penilaian, perencanaan, intervensi, dan evaluasi. Dalam tahap penilaian faktor emosional, kognitif, fisik, dan perkembangan harus dipertimbangkan. Biblioterapist sebaiknya melakukan konsultasi dengan keluarga pasien untuk mendapatkan informasi mengenai minat, kemampuan membaca, serta status mental dan emosional pasien. Proses penilaian memandu perencanaan untuk menentukan jumlah bacaan yang diberikan, tingkat kemampuan membaca, jenis bacaan, dan cara penyampaian. Selanjutnya, biblioterapist dapat mengevaluasi masalah ini dengan pasien melalui percakapan tentang kondisi medis mereka, dengan membaca bersama dan diskusi mengenai jenis bacaan apa yang diminati. Pemahaman pasien tentang masalah medis mereka dapat menjadi masukan bagi biblioterapist dalam memilih buku diberikan, apakah bertujuan untuk pengalihan perhatian, memberikan rasa aman, atau tujuan informasi.

\subsection{Tinjauan Islam}

Membaca merupakan kegiatan yang seharusnya melekat pada umat Islam. Ayat yang pertama kali di turunkan adalah perintah untuk membaca "Bacalah dengan (menyebut) nama Tuhanmu yang Menciptakan. Dia telah menciptakan manusia dari segumpal darah. Bacalah, dan Tuhanmulah Yang Paling Pemurah. Yang mengajar (manusia) dengan perantara kalam. Dia megajar kepada manusia apa yang tidak diketahuinya" (QS Al-Alaq (96) : 1-5).

Dengan membaca diharapkan pikiran pasien tidak hanya memikirkan penyakit yang dideritanya tetapi sebaliknya, membaca dapat menumbuhkan sikap sabar, tawakal, ikhlas, dan tetap optimis akan kesembuhannya, serta tidak berputus asa melakukan berbagai usaha seraya berdoa memohon kepada Allah SWT untuk memberikan kesembuhan atas ujian sakit yang diderita. Allah SWT Maha Kuasa sehingga tidak ada satu penyakitpun yang tidak bisa disembuhkan oleh Allah SWT, sesuai dengan firmanNya di surat Ash-Syu'ara (26) : 80 : "dan apabila aku sakit, maka Dia lah yang menyembuhkan penyakitku".

Dr. Al Qadhi, melalui penelitiannya yang panjang di Klinik Besar Florida Amerika Serikat, berhasil membuktikan hanya dengan mendengarkan bacaan ayat-ayat Alquran, seorang Muslim, baik mereka yang berbahasa Arab maupun bukan, dapat merasakan perubahan fisiologis yang sangat besar. Penurunan depresi, kesedihan, memperoleh ketenangan jiwa, menangkal berbagai macam penyakit merupakan pengaruh umum yang dirasakan orang-orang yang menjadi objek penelitiannya. Penemuan sang dokter ahli jiwa ini ditunjang dengan 
Bibliotech : Jurnal Ilmu Perpustakaan dan Informasi, 3 (1) 2018

bantuan peralatan elektronik terbaru untuk mendeteksi tekanan darah, detak jantung, ketahanan otot, dan ketahanan kulit terhadap aliran listrik. Dari hasil uji cobanya ia berkesimpulan, bacaan Alquran berpengaruh besar hingga 97\% dalam melahirkan ketenangan jiwa dan penyembuhan penyakit (Sumardi, 2015). Penelitian Dr. Al Qadhi ini diperkuat pula oleh penelitian lainnya yang dilakukan oleh dokter yang berbeda. Dalam laporan sebuah penelitian yang disampaikan dalam Konferensi Kedokteran Islam Amerika Utara pada tahun 1984, disebutkan, Al Qur'an terbukti mampu mendatangkan ketenangan sampai 97\% bagi mereka yang mendengarkannya (Sumardi, 2015).

Sakit merupakan salah satu bentuk ujian dari Allah SWT, namun bagi siapa yang bersabar dan ikhlas dalam menjalani cobaan dari Allah maka Allah akan memberikan Rahmat-Nya (QS Al Baqarah 55-56). Selain dijanjikan mmendapatkan pahala yang besar, diuji dengan sakit juga dapat menyebabkan gugurnya dosa. Sebagaimana sabda Rasulullah SAW : "Tidaklah seorang Muslim tertimpa suatu penyakit dan keletihan, kekawatiran dan kesedihan, dan tidak juga gangguan dan kesusahan bahkan duri yang melukainya melainkan Allah akan menghapus kesalahan-kesalahannya" (Hadist Sahih Bukhari, riwayat Tirmidzi dan Ahmad dari Abu Sa'id Al Khudri).

Kesembuhan menggunakan Alqur'an dapat dilakukan dengan membaca, berdekatan dengannya, dan mendengarkannya. Hal ini bermakna bahwa hendaknya Al Qur'an dibaca di sisi orang yang sedang menderita sakit sehingga akan turun rahmat kepada mereka.

Biblioterapi atau terapi dengan membaca (al-ilaj bil qira'ah) sebagai pengobatan mulai diterapkan di RS Al Mansur di Kairo, Mesir pada abad ke 13. Di rumah sakit itu pasien tidak hanya diberikan pengobatan medis, namun juga dibacakan ayat-ayat suci Al Qur'an setiap siang dan malam hari. Metode ini memberikan hasil yang sangat positif, yaitu selain memberikan sugesti positif kepada pasien, mereka juga merasakan kedamaian hati, sehingga memperoleh kesembuhan yang lebih cepat. Hal ini dikarenakan adanya keyakinan bahwa di antara ayat ayat suci Al Qur'an yang dibacakan, ada yang mempunyai mukzijat untuk menyembuhkan penyakit. Ayat-ayat suci Al Qur'an juga dapat memberikan keyakinan akan kekuasaan Allah SWT sehingga dapat mengurangi rasa cemas pasien (Wahab, 2013). Hal ini sesuai dengan firman Allah dalam surat Al Isra' ayat 82: “Dan Kami turunkan dari Al Quran suatu yang menjadi penawar dan rahmat bagi orang-orang yang beriman dan Al Quran itu tidaklah menambah kepada orang-orang yang zalim selain kerugian”. (QS. Al Isra (17) : 82). 
Bibliotech : Jurnal Ilmu Perpustakaan dan Informasi, 3 (1) 2018

Umar bin Khatab menyatakan bahwa "Siapa yang tidak berterapi dengan Al Qur'an maka Allah tidak akan memberi kesembuhan. Dan barang siapa yang tidak merasa cukup dengan Al Qur'an, maka Allah tidak akan memberikan kecukupan kepadanya”. Jadi selama dikaitkan dengan nama Allah (bismi rabbik), membaca itu tidak hanya baik untuk mencerdaskan umat, tapi juga menyembuhkan berbagai penyakit (Wahab, 2013).

Dalam perawatan pasien anak, biblioterapi dilakukan dengan menyampaikan kisahkisah yang ada dalam Al'Qur'an, sebagaimana diketahui bahwa sebagian besar isi dari Al Qur'an berisi kisah-kisah agar manusia dapat mengambil hikmah dan pelajaran. QS Yusuf (12) : 111). Penyampaian kisah- kisah dalam Al Qur'an dapat mengajarkan pasien anak untuk tabah dan bersabar menghadapi cobaan, misalnya dengan menyampaikan kisah tentang bagaimana Nabi Ayyub a.s yang selalu bersabar dan bertawakal kepada Allah dalam menghadapi berbagai cobaan yang datang kepadanya. Dengan cara ini pasien anak dapat lebih memahami arti kata bersabar menghadapi cobaan, karena memberi contoh dengan suatu kisah lebih sesuai dengan tingkat pemahaman pasien anak. Hal ini sesuai dengan sabda Rasulullah yang diriwayatkan oleh HR. Bukhari : “ Berbicaralah kepada orang lain sesuai dengan tingkat perkembangan akalnya. Di RSI Banyubening, layanan biblioterapi sudah melakukan p e n y e dia a n dan pembacaan kisah kisah Al Qur'an yang dapat mengajarkan anak untuk bersabar menghadapi cobaan sakit. Adapun kegiatan biblioterapi dengan pembacaan ayat-ayat suci Al Qur'an secara berkala, belum ada.

\section{KESIMPULAN}

Layanan biblioterapi yang diberikan Perpustakaan RSI Banyubening kepada pasien anak mempunyai peran penting dalam perawatan pasien anak. Dengan diberikannya layanan biblioterapi, seluruh responden menyatakan bahwa mereka menjadi senang, merasa terhibur, dan sebagian menyatakan tidak memikirkan sakitnya lagi. Orang tua responden seluruhnya menyatakan bahwa layanan biblioterapi juga bermanfaat bagi keluarga pasien. Biblioterapi di RSI Banyubening memberikan rasa senang, nyaman, menghibur, menghilangkan rasa jenuh, bahkan responden tidak memikirkan sakitnya lagi.

Biblioterapi dengan menggunakan Al Qur'an merupakan terapi yang sangat tepat untuk membantu proses penyembuhan pasien. Bacaan Al Qur'an dapat memberikan sugesti positif kepada pasien, selain juga dapat merasakan kedamaian hati dan ketenangan jiwa sehingga 
Bibliotech : Jurnal Ilmu Perpustakaan dan Informasi, 3 (1) 2018

memperoleh kesembuhan yang lebih cepat. Hal ini dikarenakan adanya keyakinan bahwa di antara ayat ayat suci Al Qur'an yang dibacakan, ada yang mempunyai mukzijat untuk menyembuhkan penyakit. Ayat-ayat suci Al Qur'an juga dapat memberikan keyakinan akan kekuasaan Allah SWT sehingga dapat mengurangi rasa cemas pasien.

\section{DAFTAR PUSTAKA}

ALA. (1983). The ALA Glossary of Library and Information Science. Chicago: American Library Association.

Apriliawati, A. (2011). Pengaruh Biblioterapi Terhadap Tingkat Kecemasan Anak Usia Sekolah Yang Menjalani Hospitalisasi di Rumah Sakit Islam Jakarta, Jakarta: Universitas Indonesia.

Bandy, M. et al., 2008. Standards for hospital libraries 2007, s.1.: Jurnal Medical Library Association.

Coyne, I. (2006). Children's experiences of hospitalization. Journal of Child Health, 10(4), pp. 326-336.

Dewi, N. \& Prihartanti, N. (2014). Metode Biblioterapi dan Diskusi Dilema Moral untuk Pengembangan Karakter Tanggungjawab. Jurnal Psikologi, 41(1), pp. 47-59.

Indonesia, K.K.R. (1994). SK Meneteri Kesehatan No. 436/MENKES/SK/VI/1993 tentang Standar Pelayanan Rumah sakit. Jakarta: Kementerian Kesehatan Republik Indonesia.

Indonesia, R. (2010). Undang-undang Republik Indonesia No. 44 Tahun 2009 tentang Rumah Sakit. Jakarta: Kementerian Kesehatan Republik Indonesia.

Lucas, C.V. \& Soares, L. (2013). Bibliotherapy: A tool to promote children's psychological well-being. Journal of Poetry Therapy, 26(3), pp. 137-147.

McMillen, P.S. \& Pehrsson, D.E. (2008). Bibliotherapy for Hospital Patients. Journal of Hospital Librarianship, 4(1), pp. 73-81.

Nurgiyantoro. (2005). Tahapan perkembangan anak dan pemilihan bacaan sastra anak. Cakrawala Pendidikan, XXIV(2).

Pehrsson, D. \& McMillen, P.S. (2005). A Bibliotherapy evaluation tool: Grounding counselors in the therapeutic use of literature. Nevada: University of Nevada Las Vegas.

Sherrill, W.W. \& Harris, M. (2014). Enhancing patient-provider communication through bibliotherapy: A brief historical review. Journal of Poetry Therapy,27(2), pp. 89-96. 
Bibliotech : Jurnal Ilmu Perpustakaan dan Informasi, 3 (1) 2018

Sumardi, E. (2015). Tribun Timur. [Online] Available at: makassar.tribunnews.com [Diakses 20 Agustus 2016].

Yoanda, S. \& Ismayati, N. (2015). Layanan Biblioterapi Untuk Pasien Kanker Anak di RSUP Fatmawati Jakarta. Jurnal Al-Kuttab, Jurnal Perpustakaan dan Informasi, Volume 2, pp. $124-138$.

Wahab, M.A. (2013). Republika Online. [Online] Available at: http://www.khazanah. republika.co.id_[Diakses 1 Agustus 2016]. 
Bibliotech : Jurnal Ilmu Perpustakaan dan Informasi, 3 (1) 2018 